\title{
Excipients of Inhaled Medications With Potential to Cause Adverse Reactions
}

\author{
Dejan Ž. Kusonić ${ }^{1}$, Katarina Z. Petronijević ${ }^{1}$, Jelena M. Čanji Panić

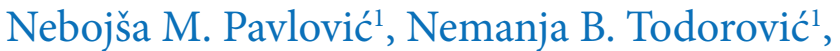 \\ Branislava U. Srđenović Čonić1,2, Sonja Lj. Šušnjevićc ${ }^{3}$, \\ Mladena N. Lalić-Popović ${ }^{1,2}$
}

\begin{abstract}
${ }^{1}$ Department of Pharmacy, Faculty of Medicine Novi Sad, University of Novi Sad, Novi Sad, Serbia

${ }^{2}$ Center for Medical and Pharmaceutical Investigations and Quality Control (CEMPhIC), Faculty of Medicine Novi Sad, University of Novi Sad, Novi Sad, Serbia

${ }^{3}$ Institute of Public Health of Vojvodina, Faculty of Medicine, University of Novi Sad, Novi Sad, Serbia
\end{abstract}

\section{SUMMARY}

Introduction: In addition to the active pharmaceutical ingredient (API), the composition of the medicines also includes excipients which are only ideally completely pharmacologically inactive. It has been shown that excipients in inhaled preparations can cause effects opposite to the pharmacological effect of the medicine.

Aim: The Aim of the study was to identify potentially harmful excipients in inhaled medicines approved in the Republic of Serbia.

Material and Methods: The academic study was conducted during April 2021 and included the analysis of medicines that received a marketing authorization from the Medicines and Medical Devices Agency of Serbia (ALIMS). Qualitative compositions of inhaled medicines available in Summaries of product characteristics (SmPC) on the ALIMS's official website were observed. Excipients considered potentially harmful if they are recognised as excipients with known effect (EKE) in Serbian and European regulations.

Results: Total of 46 inhalation preparations that are approved in Serbia were analyzed. In their composition were found 17 different excipients. By comparing appropriate domestic and European regulations three excipients from examined preparations that represent potential causative agents of adverse drug reactions (ADRs) were identified: lactose-monohydrate, ethanol and benzalkonium chloride. It has been shown that disodium EDTA is also a potential causative agent of ADRs, but it is not classified as EKE.

Conclusion: Neither domestic nor international regulations have classified EDTA and its salts as EKE and they should be given special attention in the future as potential causative agents of ADRs. It has been shown that benzalkonium chloride is the only excipient that can lead to bronchospasm and it was found in two inhaled medicines.

Keywords: Excipients With Known Effect, Pharmacovigilance, Bronchoconstriction 


\section{INTRODUCTION}

When we talk about efficacy, safety and quality of medicines, they primarily depend on the API but also to a large extent on the production processes by which these medicines are obtained, as well as on excipients that enter their composition. Over time, the understanding of the importance of excipients has changed. Initially, they were considered cheap and inert substances, while today they are considered very important ingredients that are part of medicines and that affect their characteristics together with API. A large number of substances with their structure ranging from small molecules to large, complex polymeric structures of natural or synthetic origin are used today in the pharmaceutical industry as excipients [1].

Serbian Law on Medicines and Medical Devices defines excipients as substances used in manufacture of medicines and do not constitute their active ingredient but help in pharmaceutical formulation of medicines, protect, support or improve the stability, bioavailability and tolerability of medicines, and assist in their identification [2]. They can be of different origins: animal (lactose, gelatin), herbal (cellulose, starch), mineral and synthetic (povidone, polysorbates) [3].

Pharmaceutical dosage forms are solid, semi-solid or liquid dispersion systems in which excipient have two main roles. One is to represent a filler or solvent (vehicle) thus ensuring that the dose of API has appropriate weight, volume and consistency that allows delivery of API to the desired place of absorption, while the other role is to represent adjuvants that allow adequate release of API [1].

Excipients in the preparation must meet three important conditions which are functionality, quality and safety. A very important condition is safety which is often not given much attention, because in many cases excipients are considered to be completely inert [3]. This information is taken with caution, because excipients in their original form, in doses and concentrations that are commonly used can cause different problems and they can react in various ways and lead to the same problems in the presence of various environmental factors [1]. In the Serbian market, in effervescent dosage forms the sodium level can be up to $271,50 \%$ of the adequate daily intake when the maximum daily dose of drug is ad- ministrated [4]. This leads us to another very important and desirable characteristic that is not always satisfied in all patients. That is pharmacological and toxicological inactivity [1].

Because of inertia as characteristic often attributed to excipients, health care professionals in most cases consider ADRs to occur as a consequence of API. On the other hand, due to the lack of information and knowledge in this field, patients very often do not know they exist in medicines [5]. As many as twothirds of drugs have the potential to cause non-API related ADRs [6]. Article 2 of Serbian Law on Medicines and Medical Devices defines ADRs as any harmful and unintentional reaction to a medicines that occurs after administration of the usual dose of the drug to humans and animals (for the purpose of the treatment, disease prevention, diagnosis, restoration, improvement or change of physiological function) or when administering any dose of the medicines during the clinical trial [2]. In addition to ADRs, it is very important to define term EKE. They represent all those excipients that are in the composition of various medicines and can cause certain problems [7]. In the Republic of Serbia, all necessary data on EKE can be found in the Rulebook of content and manner of marketing the outer and inner packaging of the medicines, additional labeling, as well as the content of the package leaflet, while in the European Union the European Medicines Agency's (EMA) EKE list also includes an annex on the listing and labeling of excipients on the packaging of medicinal products intended for human use [6]. Excipients can lead to ADRs by a direct effect through their functional groups or they can occur as a consequence of the presence of impurities in their composition [7]. As a consequence, the toxicity can occur on the population level, which depends primarily on the dose of the excipient, or toxicity at the individual level, which depends in part on the dose and to a greater extent on the individual characteristics of the individual [3].

When it comes to inhalation preparations, European Pharmacopoeia (Ph. Eur. 10) defines them as liquid or solid preparations intended for use in the lungs in the form of vapor or aerosols with the aim of achieving a local or systemic effect. Achieving a systemic 
effect using the lungs as a route of medicine administration is very effective due to the extremely large absorption surface, thin absorption membrane, increased blood flow and low metabolic activity. Therefore, inhalation therapy has a number of advantages over other routes of medicine administration. The three most important are rapid action, bypassing the effect of the first passage through the liver and lower doses of the drug, which is why there is a less possibility of systemic ADRs. This type of therapy is most often used as a choice in the treatment of asthma and chronic obstructive pulmonary disease (COPD). The efficiency of the inhaled aerosol is mainly influenced by the size $(0,5-5 \mu \mathrm{m})$, shape and density of the particles of the given aerosol. This group of preparations includes dry inhalation powders (DPIs), metered-dose inhalers (MDIs) and nebulizer solutions (nebulizers), which contain appropriate API and excipients.

DPIs often contain excipients as API particle carriers. In this case, the excipients form a larger part of the formulation in order to enable appropriate application, release and dosing of the drug. The most commonly used excipient in this group is lactose. When it comes to nebulizer solutions, excipients with the role of the preservatives or in order to improve chemical stability are most often added $[8,9]$. One of them is phenol which can lead to respiratory tract irritation, coughing and even bronchoconstriction. In addition, phenol leaves an unpleasant taste in the mouth and it is also classified as a neurotoxin. Sodium chloride is added as an osmolarity correction agent, while hydrochloric acid, sodium hydroxide, citric acid and phosphates are added as $\mathrm{pH}$ adjusting agents. The composition of MDI in terms of excipients is very similar to that in nebulizer solutions with the difference of the presence of propellants HFA 134a and HFA 227, which are considered excipients [9]. For excipients intended for use in inhalation preparations it is necessary to report completely safety tests for such a method of administration. In this preparations excipients can be found in solid, liquid and gaseous state [10]. Those in the gaseous state have the role of a propellant and must meet special requirements such as non-toxicity, non-flammability and compatibility with API and packaging (pressurized bottles) [11].

Due to limited number of excipients that can be found in inhaled preparations, the complexity of production processes, as well as the ADRs that excipients can lead to, there is a growing interest in making formulations of inhaled preparations without the presence of excipients.

\section{AIM}

The aim of this study was to detect excipients that can be found in the formulations of inhaled preparations registered in the territory of the Republic of Serbia, which are potential causative agents of ADRs. In addition, the aim was to compare relevant domestic and European regulations in this area.

\section{MATERIAL AND METHODS}

In the academic study, medicines for inhalational route of administration were analyzed. SmPC available on the official web site of ALIMS [12] were sources of data about qualitative content of approved medicines in Republic of Serbia. Chapter 6. (Pharmaceutical data) and subchapter 6.1. (List of excipients) were observed for searching present excipients.

Appropriate domestic and European regulations were used as a source of data on EKE. Domestic regulations are the mentioned Rulebook on the content and manner of labeling the outer and inner packaging of the drug, additional labeling, as well as the content of the instructions for the drug, which contains the attached table with data on EKE and can also be found on the official website of ALIMS [13]. On the other hand, the European regulation is appropriate annex on the listing and labeling of excipients on the packaging of drugs intended for human use and is available on the official website of the EMA [14]. Excipients were recorded as EKE if they are listed in these regulation acts.

The results are presented in a table where the first column presents the names of excipients that can be found in the formulations of inhalation preparations registered in the territory of Republic of Serbia and represent potential causative agents of ADRs, the second their application, the third tolerance threshold, the fourth their potential ADRs and the fifth their presence in formulations of inhalation preparations registered in the territory of Republic of Serbia, presented as a percentage of the absolute value. 
Table 1. List of excipients that are part of 46 tested formulations of inhalation preparations registered on the territory of the Republic of Serbia, their functional category, chemical structure and presence in these formulations expressed as an absolute value and a percentage of that value

\section{RESULTS}

A total of 46 medicines (formulations of inhaled preparations) approved on the territory of the Republic of Serbia were analyzed in this study and all of them in their composition contain at least one of the 17 detected excipients.

Domestic and European regulations that were the source of data on EKE contain the same parts. Those are the name of EKE, method of administration, tolerance threshold and data in the package leaflet and comment, but they are not fully harmonized, in terms of method of application and threshold tolerance values.

Based on the scientific data, data from Table 1 and data obtained from the aforementioned regulations and by comparing them, a list of excipients was found which are in the formulations of inhaled preparations registered in the territory of the Republic of

\begin{tabular}{|c|c|c|c|c|}
\hline Excipient & $\begin{array}{l}\text { Functional } \\
\text { category }\end{array}$ & Chemical structure & Presence & $\begin{array}{l}\text { Presence } \\
\text { (\%) }\end{array}$ \\
\hline $\begin{array}{l}\text { Lactose- } \\
\text { monohydrate }\end{array}$ & carrier & $\mathrm{OH}_{\mathrm{H}}-\mathrm{O}_{-\mathrm{H}}$ & $23 / 46$ & 50 \\
\hline $\begin{array}{l}\text { Norflurane } \\
\text { (HFA 134a) }\end{array}$ & propellant & $\mathrm{F}_{\mathrm{F}}^{\mathrm{F}}$ & $11 / 46$ & 23,91 \\
\hline Ethanol & $\begin{array}{l}\text { solvent, } \\
\text { antimicrobial } \\
\text { preservative }\end{array}$ & & $8 / 46$ & 17,39 \\
\hline $\begin{array}{l}\text { Magnesium- } \\
\text { stearate }\end{array}$ & lubricant & & $7 / 46$ & 15,22 \\
\hline $\begin{array}{l}\text { Water } \\
\text { (purified) }\end{array}$ & solvent & $\mathrm{H}^{-} \mathrm{O} \cdot \mathrm{H}$ & $4 / 46$ & 8,70 \\
\hline $\begin{array}{l}\text { Hydrochloric } \\
\text { acid }\end{array}$ & $\begin{array}{l}\text { pH adjusting } \\
\text { agent }\end{array}$ & $\mathrm{H}-\mathrm{Cl}$ & $4 / 46$ & 8,70 \\
\hline Gelatin & $\begin{array}{l}\text { coating and } \\
\text { viscosity } \\
\text { increasing agent }\end{array}$ & $\begin{array}{l}\text { Purified protein obtained from collagen of } \\
\text { animals }\end{array}$ & $3 / 46$ & 6,52 \\
\hline Hypromellose & $\begin{array}{l}\text { Viscosity } \\
\text { increasing agent }\end{array}$ & $\mathrm{R}=-\mathrm{H},-\mathrm{CH}_{3},-\mathrm{CH}$ & $2 / 46$ & 4,35 \\
\hline Citric acid & $\begin{array}{l}\text { pH adjusting } \\
\text { agent }\end{array}$ & $\mathrm{R}=-\mathrm{H}_{1}-\mathrm{CH}_{3},-\mathrm{CH}_{2}-\mathrm{CHOH}_{-} \mathrm{CH}_{3}$ & $2 / 46$ & 4,35 \\
\hline $\begin{array}{l}\text { Benzalkoni- } \\
\text { um-chloride }\end{array}$ & preservative & $\begin{array}{l}n=8,10,12,14,16,18 \\
\mathrm{H}_{3} \mathrm{C}^{\prime} \mathrm{CH}_{3}\end{array}$ & $2 / 46$ & 4,35 \\
\hline
\end{tabular}




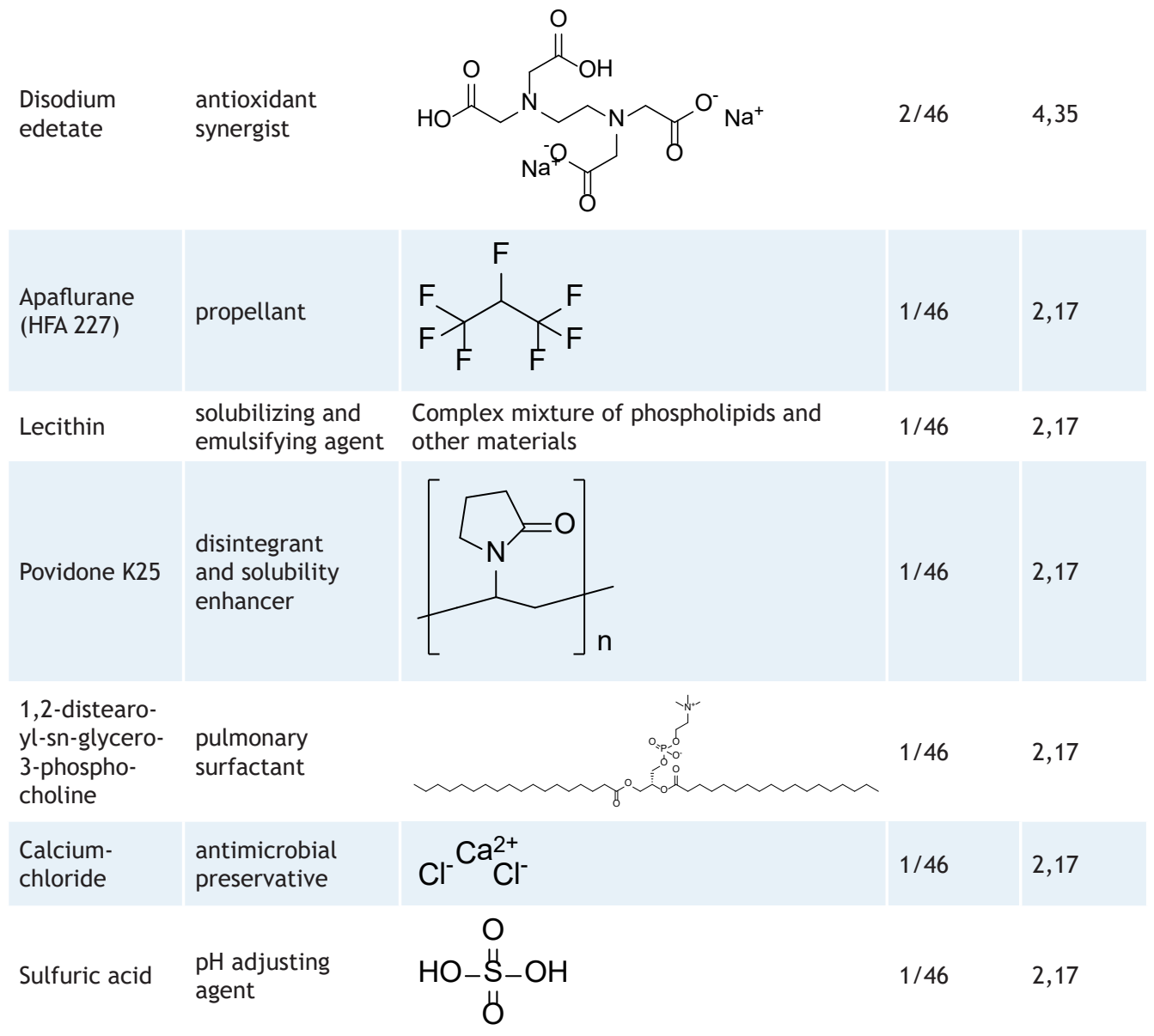

\begin{tabular}{|c|c|c|c|c|}
\hline Excipient & $\begin{array}{l}\text { Method of } \\
\text { application }\end{array}$ & $\begin{array}{l}\text { Tolerance } \\
\text { threshold }\end{array}$ & Potential ADRs & $\begin{array}{c}\text { Presence } \\
\text { (\%) }\end{array}$ \\
\hline $\begin{array}{l}\text { Lactose- } \\
\text {-monohydrate }\end{array}$ & Per os & $\begin{array}{l}0 \\
5 g\end{array}$ & $\begin{array}{l}\text {-Danger for patients } \\
\text { who have intolerance } \\
\text { to lactose } \\
\text {-The possibility of } \\
\text { anaphylaxis }\end{array}$ & 50 \\
\hline Ethanol & $\begin{array}{l}\text { Domestic regulation: } \\
\text { Per os } \\
\text { Parenteral } \\
\text { European regulation: } \\
\text { Per os } \\
\text { Parenteral } \\
\text { Inhalation } \\
\text { Dermal }\end{array}$ & $\begin{array}{l}\text { Domestic regulation: } \\
<100 \mathrm{mg} / \text { dose } \\
100 \mathrm{mg}-3 \mathrm{~g} / \text { dose } \\
3 \mathrm{~g} / \mathrm{dose} \\
\text { European regulation: } \\
0 \\
15 \mathrm{mg} / \mathrm{kg} / \text { dose } \\
75 \mathrm{mg} / \mathrm{kg} / \text { dose }\end{array}$ & $\begin{array}{l}\text {-It showed genotoxic- } \\
\text { ity, teratogenicity and } \\
\text { reproductive toxicity } \\
\text { in higher doses than } \\
\text { allowed and low acute } \\
\text { toxicity in inhalation } \\
\text { formulations } \\
\text {-Special caution in } \\
\text { persons with hepatic } \\
\text { impairment, children, } \\
\text { pregnant and lactating } \\
\text { women }\end{array}$ & 17,39 \\
\hline $\begin{array}{l}\text { Benzalkonium- } \\
\text {-chloride }\end{array}$ & $\begin{array}{l}\text { Domestic regulation: } \\
\text { Ophtalmic } \\
\text { Local } \\
\text { Inhalation } \\
\text { Parenteral } \\
\text { European regulation: } \\
\text { All routes of applica- } \\
\text { tion }\end{array}$ & $\begin{array}{l}\text { Domestic regulation: } \\
0 \\
10 \mu \mathrm{g} / \mathrm{dose} \\
<90 \mathrm{mg} / \mathrm{kg} / \text { daily } \\
90 \mathrm{mg} / \mathrm{kg} / \text { daily } \\
\text { European regulation: } \\
0\end{array}$ & $\begin{array}{l}\text {-Depending on the } \\
\text { route of application } \\
\text { it can lead to an eye } \\
\text { and skin irritation, } \\
\text { allergic reactions and } \\
\text { bronchospasm } \\
\text {-It should not be given } \\
\text { to premature babies } \\
\text { and newborns }\end{array}$ & 4,35 \\
\hline $\begin{array}{l}\text { Disodium } \\
\text { edetate }\end{array}$ & l & I & l & 4,35 \\
\hline
\end{tabular}

Table 2. List of excipients that are part of 46 tested formulations of inhalation preparations registered in the territory of the Republic of Serbia and represent potential causative agents of ADRs, their method of application, tolerance threshold, potential ADRs, as well as their presence in these formulations expressed as a percentage of an absolute values 
Serbia and represent potential causative agents of ADRs.

\section{DISCUSSION}

The safety of inhalation formulations is well proven, but the proven safety does not guarantee the absence of ADRs, so there have been cases where side effects have occurred. These side effects can occur as a consequence of appropriate characteristics and very often as a consequence of the presence of certain excipients [15].

In this paper, on the basis of all obtained and collected data, four excipients in authorized formulations of inhalation preparations that represent potential causative agents of ADRs were isolated.

Benzalkonium chloride (BAC) is a quaternary ammonium compound that is most commonly used as a preservative in preparations. It shows activity mostly against gram-positive bacteria, but also to a small extent against gram-negative and anaerobic bacteria. It has many side effects such as side effects on the skin, eye, ear and respiratory system. When it comes to the effects on the respiratory system it has been shown that they are the result of an allergic reaction due to the release of histamine. In one case, three year old boy with asthma experienced coughing, wheezing and cyanosis on two occasions after the application of beclomethasone in the form of nebulizer. Beasley and his co-workers speculated that benzalkonium chloride, a preservative in beclomethasone suspension, could be responsible. Additionally, Beasley and his co-workers conducted a study on 20 asthma patients who received ipratropium bromide in combination with benzalkonium chloride as an excipient or without it. Six patients developed bronchoconstriction following benzalkonium chloride preserved ipratropium and a maximal decrease of $35 \%$ in FEV1 occurred in first two minutes after ipratropium use [16]. In another case, it has been shown that double doses of BAC cause bronchoconstriction in 25 of 28 patients, whereas 17 of 28 had at least a $20 \%$ decrease in FEV1. Based on all this it was concluded that BAC administered as a preservative at a dose higher than $5 \mu \mathrm{g} / \mathrm{ml}$ may be the cause of such effects by the mechanism of histamine release $[15,16]$. The solution to this case is that in inhaled preparations BAC is always combined with sympathomimetic bronchodilatators which are its functional antagonists. When it comes to nasal drops that contains $\mathrm{BAC}$ as a preservative, it has been shown that they can cause nasal congestion and burning of the eyes. After prescribing appropriate symptomatic therapy the condition worsened. Also, Lefler's syndrom, a rare lung disease, has been observed in a couple of cases in patients who used nasal drops that contained phenylephrine, tenyldiamine and $\mathrm{BAC}$ as a preservative $[15,16]$. Although nasal drops are not a formulation that has an inhalation route of administration, due to the presence of BAC as a preservative in their composition and anatomical proximity, as well as the connection of these data with the occurrence of Lefler syndrom, it is important to mention them.

Ethylenediaminetetraacetic acid (EDTA) and its salts in pharmaceutical formulations usually have the role of a chelating agent and form soluble complexes with metal ions. The stability of this complex mainly depends on the metal ion and $\mathrm{pH}$ value. Their primary role in the preparation is reflected in their antioxidant effect. In aforementioned study conducted by Beasley and his co-workers on 20 asthma patients, EDTA used in the ipratropium solution have also contributed to the bronchoconstriction, since dose-related bronchoconstriction was also demonstrated following inhalation of edetic acid solution alone [16]. Additionally, it has been shown that EDTA in combination with benzalkonium chloride produce an inflammatory reaction and microscopic examination showed an extended infiltration of the mucosa by eosinophils, pronounced atrophy and disorganization of the epithelium, although these effects were subsequently shown to be reversible [17]. This is of particular importance because neither domestic nor international regulations have classified EDTA and its salts as EKE.

Lactose-monohydrate is a disaccharide originating from milk and in its composition it contains one molecule of glucose and one molecule of galactose interconnected by $(1 \rightarrow 4)$ glycosidic bond. It is most often used as a filler and binding agent in the production of tablets and capsules. When it comes to inhalation formulations, especially DPI, it has the role of a carrier [17]. Adverse reactions that occur after the use of preparations that contain lactose in their composition are a consequence of intolerance. There is a lack of the enzyme 
lactase which has a role in metabolizing lactose and as a consequence milder forms of side effects can occur, as well as an anaphylactic reaction. In one case report, a nine year-old African American boy with a history of persistent asthma was hospitalized due to the development of an anaphylactic reaction as a consequence of lactose intolerance after administration of inhalation medicine [18].

Research related to ethanol has shown greater interest in its use as a basic ingredient in various beverages, while much less attention has been paid to its role as an excipient in pharmaceutical preparations. As a consequence, we have very little data on its harmful effects when applied as an excipient. Appropriate preclinical studies in rats shown that ethanol possess genotoxicity when administered at a dose much higher than permitted, as well as teratogenicity and reproductive toxicity. When it comes to the use of ethanol within inhalation preparations, it has been shown to have a very low degree of acute toxicity [19]. It has been shown to be particularly harmful in newborns and therefore its use in formulations intended for use in children is strictly regulated, respectively it is advised to avoid its use in these preparations [20]. The World Health Organization (WHO) has defined the limits of ethanol that can be found in preparations used in children. They are less than $0,5 \%$ for children under the age of six, less than $5 \%$ for children from age of six up to age of twelve and less than $10 \%$ for children older than twelve years old [21].

\section{CONCLUSION}

It has been shown that BAC, lactose-monohydrate, EDTA and ethanol are excipients that are potential causative agents of ADRs and they are part of 46 tested formulations of inhaled preparations registered in the territory of the Republic of Serbia. The most common ADRs they cause are bronchoconstriction that can occur when using BAC and EDTA as excipients, milder forms of symptoms and anaphylactic reaction as a result of lactose intolerance and a low degree of acute toxicity when using ethanol in inhaled preparations, while in higher doses than allowed can lead to the occurrence of genotoxicity, teratogenicity and reproductive toxicity. As EDTA and its salts are not classified by either domestic or international regulations as EKE, they should be given special attention in the future as po- tential causative agents of ADRs. It has also been shown that of the mentioned excipients lactose-monohydrate is the most represented in preparations on our market with as much as $50 \%$ presence, while $\mathrm{BAC}$ is the causative agent of the most severe ADRs.

\section{CONFLICT OF INTEREST}

All authors declare no conflict of interest.

\section{REFERENCES}

1. Pifferi G, Santoro P, Pedrani M. Quality and functionality of excipients. II Farmaco. 1999;54(1-2):14.

2. www.paragraf.rs [homepage on the internet]. Belgrade: Paragraf Lex. 1996 [cited 2021 March 14]. Available from: http://www.paragraf.rs/propisi/zakon_o_lekovima_i_medicinskim_sredstvima_. html

3. Pifferi G, Restani P. The safety of pharmaceutical excipients. II Farmaco. 2003;58(8):541-50.

4. Čanji JM, Todorović NB, Čović BZ, Pavlović NM, Jovičić-Bata JN, Goločorbin-Kon SS et al. Drug sodium intake: Warning in cardiovascular diseases treatment. Hospital Pharmacology-International Multidisciplinary Journal. 2020;7(2):913-22.

5. Scott AW. Non-medicinal ingredients. Drug Saf. 1990;5(1):95-100.

6. Todorović NB, Goločorbin-Kon SS, Pavlović NM, Čanji JM, Jeremić KD, Milijašević BŽ et al.. The significance of dosage forms for pharmacovigilance in the case of topical corticosteroids. Hospital Pharmacology-International Multidisciplinary Journal. 2019;6(2):800-6.

7. Crowley P, Martini LG. Drug-excipient interactions. Pharm Technol. 2001;4:7-12.

8. Vasiljević D, Primorac M. Pharmaceutical-technological characteristics of modern inhalation drugs in pulmonary disease therapy. Arhiv za farmaciju. 2011;61(2):226-47.

9. Pilcer G, Amighi K. Formulation strategy and use of excipients in pulmonary drug delivery. Int $\mathrm{J}$ Pharm. 2010;392(1-2):1-9.

10. Weiner ML, Kotkoskie LA. Excipient toxicity and safety. New York: Marcel Decker, Inc;2000.

11. Kalasz H, Antal I. Drug excipients. Curr Med Chem. 2006;13(21):2535-63.

12. alims.gov.rs/ciril/ [homepage on the internet]. Belgrade: ALIMS. 2004 [cited 2021 March 14]. Available from: http://www.alims.gov.rs/ciril/lekovi/ pretrazivanje-humanih-lekova

13. alims.gov.rs/ciril/ [homepage on the Internet]. 
Belgrade: ALIMS. 2004 [cited 2021 March 14]. Available from: http://www.alims.gov.rs/ciril/regulativa/humani-lekovi/pravilnici/

14. ema.europa.eu/en [homepage on the internet]. London: EMA. 1995 [cited 2021 March 14]. Available from: http://www.ema.europea.eu/en/ documents/scientific-guideline/annex-europeancommission-guideline-excipients-labelling-package-leaflet-medicinal-products-human_en.pdf

15. Asmus MJ, Sherman J, Hendeles L. Bronchoconstrictor additives in bronchodilator solutions. J AllergyClin Immunol. 1999;104(2):S53-60.

16. Golightly LK, Smolinske SS, Bennett ML, Sutherland EW, Rumack BM. Pharmaceutical excipients. Med Toxicol Adverse Exp. 1988;3(2):128-165.

17. Rowe RC, Sheshey PJ, Quinn ME. Handbook of pharmaceutical excipients. 6th edition. London:Pharmaceutical Press;2009.

18. Robles J, Motheral L. Hypersensitivity reaction after inhalation of lactose-containing dry powder inhaler. J Pediatr Pharmacol Ther. 2014;19(3):20611.

19. CHMP. Information for the package leaflet regarding ethanol used as an excipient in medicinal products for human use. Ema.europea.eu [homepage on the internet]. 2004 [cited 2021 March 14]. Available from: www.ema.europea.eu/en/

20. Christiansen N. Ethanol exposure through medicines commonly used in paediatrics. Arch Dis Child Educ Pract Ed. 2015;100(2):101-4.

21. ema.europea.eu/en [homepage on the Internet]. London: EMA. 1995 [cited 2021 March 14]. Available from: http://www.ema.europa.eu/en/ documents/scientific-guideline/questions-answersethanol-context-revision-guideline-excipients-label-package-leaflet-medicinal_en.pdf 


\title{
Ekscipijensi u inhalacionim lekovima koji mogu izazvati neželjene reakcije
}

\author{
Dejan Ž. Kusonić1, Katarina Z. Petronijević ${ }^{1}$, Jelena M. Čanji Panić1, \\ Nebojša M. Pavlović ${ }^{1}$, Nemanja B. Todorović ${ }^{1}$, Branislava U. Srđenović Čonićn ${ }^{1,2}$, \\ Sonja Lj. Šušnjevićc ${ }^{3}$, Mladena N. Lalić-Popović1,2 \\ ${ }^{1}$ Katedra za farmaciju, Medicinski fakultet Novi Sad, Univerzitet u Novom Sadu, Novi Sad, Srbija \\ ${ }^{2}$ Centar za medicinsko-farmaceutska istraživanja i kontrolu kvaliteta (CEMFIK), Medicinski fakultet Novi \\ Sad, Univerzitet u Novom Sadu, Novi Sad, Srbija \\ ${ }^{3}$ Institut za javno zdravlje Vojvodine, Medicinski fakultet, Univerzitet u Novom Sadu, Novi Sad, Srbija
}

\section{KRATAK SADRŽAJ}

Uvod: Pored aktivnog farmaceutskog sastojka (API), u sastav lekova obično ulaze $i$ pomoćne supstance koje su samo idealno potpuno farmakološki neaktivne. Pokazano je da pomoćne supstance u inhalacionim preparatima mogu izazvati efekte suprotne farmakološkom dejstvu leka.

Cilj: Cilj studije bio je identifikovanje potencijalno štetnih pomoćnih supstanci u lekovima za inhalaciju odobrenim u Republici Srbiji.

Metodologija: Studija je sprovedena tokom aprila 2021. godine i obuhvatila je analizu lekova koji su dobili dozvolu za stavljanje u promet Agencije za lekove i medicinska sredstva Srbije (ALIMS). Beleženi su kvalitativni sastavi inhalacionih lekova koji su dostupni u sažecima karakteristika lekova (SmPC) na zvaničnoj veb stranici ALIMS-a. Pomoćne supstance su smatrane potencijalno štetnim ako su prepoznate kao pomoćne supstance sa poznatim dejstvom (EKE) u srpskim i evropskim propisima.

Rezultati: Ukupno 46 inhalacionih preparata koji su odobreni u Srbiji su analizirani. U njihovom sastavu pronađeno je 17 različitih ekscipijenasa. Poređenjem odgovarajućih domaćih i evropskih propisa identifikovane su tri pomoćne supstance iz ispitivanih preparata koji predstavljaju potencijalne uzročnike neželjenih dejstava (ADRs): laktoza-monohidrat, etanoli benzalkonijum-hlorid. Pokazano da je dinatrijum EDTA takođe potencijalni uzročnik neželjenih efekata, ali nije klasifikovan kao EKE.

Zaključak: Ni domaći ni međunarodni propisi nisu klasifikovali EDTA i njene soli kao EKE i njima bi u budućnosti trebalo posvetiti posebnu pažnju kao potencijalnim uzročnicima ADRs. Benzalkonijum hlorid je jedini ekscipijens koji može dovesti do bronhospazma i bio je prisutan u dva inhalaciona leka.

Ključne reči: dekscipijensi sa potvrđenim delovanjem, farmakovigilanca, bronhokonstrikcija 